No $2008-21$

October

\title{
CEPII
}

Cax rex

D'RTUDE PBOSPECTIVE

ET D'INFOEMATIONS

INTERNATIONALE

\section{The Euro Effects} on the Firm and Product-Level Trade Margins:

Evidence from France

Antoine Berthou

Lionel Fontagné 
The Euro Effects on the Firm and Product-Level Trade Margins: Evidence from France

Antoine Berthou Lionel Fontagné

No $2008-21$

October 


\section{TABLE OF CONTENTS}

1. Data and Methodology 11

1.1. Data . . . . . . . . . . . . . . . . . 11

1.2. Estimation methodology $\ldots \ldots \ldots \ldots 13$

1.3. Stylized facts . . . . . . . . . . . . . . . . . 17

2. Empirical Results 19

2.1. Full sample estimates . . . . . . . . . . . . . . . . . . . . . . . 19

2.2. Sub-samples of firms . . . . . . . . . . . . . . 21

2.3. Euro effect and productivity $\ldots \ldots \ldots \ldots \ldots$

3. Conclusions 25 


\section{THE EURO EFFECTS on the Firm and Product-Level Trade Margins: Evidence from France}

\section{NON-TECHNICAL SUMMARY}

The macroeconomic impact of euro adoption on trade flows has been widely examined and quantified: the value of trade flows between insiders has increased by less than $10 \%$ since 1999. Though, a clear description of the adjustments that occurred between and within firms is still lacking. The New New Trade Theory is helpful to identify the micro-level adjustments that we should expect. These adjustments consecutive to a decrease in trade costs can occur through the selection of firms (the firm-level trade margins), through the within-firm section of products that are exported (the product extensive margin), and through the value of exports by product (the product intensive margin). This article addresses the following questions: did euro adoption affect the selection of exporters? Did the number of products exported by firm vary? Did the value of exports by product within incumbent exporters raise? What are the characteristics of the firms that have benefited from euro adoption?

Product-level trade databases do not allow to properly test the predictions of the New New Trade Theory. This paper makes use of the French firm-level export data provided by the French customs, over the period 1995-2003. We also make use of a French business survey ("Enquête Annuelle d'Entreprises, EAE") that reports the individual characteristics of French firms with more than 20 employees. This second database can be matched with the customs data to investigate how the euro effects on French exporters interact with their individual characteristics, in particular their size and productivity.

We successively estimate the effects of the introduction of the euro on the export decision, the number of products exported by firm, and the value of exports by product by firm, for the full sample of French exporters. Second, we investigate whether the estimation results for the full sample of firms are subject to a composition effect, since the majority of observation in the data relate to very small firms that export only occasionally. Finally, we control for productivity, and examine whether the euro effects interact with the productivity of the firm before the euro introduction.

Estimation results that rely on the full sample of exporters show that the effects of the euro on trade mainly channel through the number of products exported by firm in the French case. We note however a positive effect on the value of exports by product, when we restrict the sample of exporters to firms with more than 20 employees. This tends to support the existence of a composition effect. Finally, while results remain unchanged when we control for the productivity of the firm, we also find evidence that the euro effect is dramatically reduced for the $25 \%$ of firms reporting the lowest productivity level before its introduction.

\section{Abstract}

We investigate the effects of the euro on French exporters. We build three margins corresponding to the decision of exporting, the number of products exported to each destination, 
and the average value of exports by product, that compose the expected value of exports of each individual firm on a market. Estimation results that rely on the full sample of exporters suggest that the euro adoption had a positive effect on the number of products exported by each individual firm, and no effect on the decision to export and the average value of exports by product. Though, composition effects are in action: the effect on the decision of exporting, and on the average value of exports by products, is positive - but weakly significant for firms with more than 20 employees. Finally, we find that euro had no effect on least productive firms.

JEL Classification: F15.

Keywords: trade, export margins, euro 


\section{L'IMPACT DE L'EURO SUR LES MARGES DU COMMERCE AU NIVEAU DES FIRMES ET} PRODUITS

\section{RESUME NON TECHNIQUE}

L'impact macroéconomique de l'adoption de l'euro sur les échanges commerciaux a été largement examiné et quantifié : la valeur des flux commerciaux entre pays membres a été augmentée de moins de 10\% depuis 1999. Il manque toutefois une description claire des ajustements qui ont eu lieu entre firmes et au sein des firmes. La nouvelle nouvelle théorie du commerce international permet d'identifier les ajustements microéconomiques escomptés. Ces ajustements, consécutifs à une baisse des coûts d'échange, peuvent passer par la sélection des firmes (la marge du commerce au niveau des firmes), la sélection des produits exportés par chaque firme (la marge extensive produit) ou la valeur des exportations par produit (la marge intensive produit). Cet article se propose alors d'examiner les questions suivantes : l'introduction de la monnaie unique a-t-elle affecté la sélection des exportateurs? le nombre de produits exportés par firme a-t-il changé ? la valeur des exportations par produit des firmes en place a-t-elle augmenté ? enfin, quelles sont les caractéristiques des firmes ayant bénéficié de l'adoption de l'euro?

Les bases de données d'échange détaillées au niveau des produits ne permettent pas de tester les prédictions de la nouvelle nouvelle théorie du commerce international. Cet article s'appuie sur les données individuelles d'exportation des firmes françaises sur la période 19952003 mises à notre disposition par la Direction Générale des Douanes et des Droits Indirects (DGDDI). Nous utilisons également l'Enquête Annuelle des Entreprises (EAE) qui renseigne les caractéristiques individuelles des entreprises françaises de plus de 20 salariés. Cette deuxième base de données peut être appariée avec les données individuelles douanières pour examiner comment l'impact de l'introduction de l'euro interagit avec ces caractéristiques, s'agissant en particulier de la taille et de la productivité des entreprises.

Considérant l'ensemble des exportateurs français, nous examinons successivement les effets de l'introduction de l'euro sur la décision d'exportation, sur le nombre de produits exportés par firme et sur la valeur des exportations par produit et par firme. Dans un second temps, nous recherchons si les résultats obtenus dans cette première étape sont affectés par un effet de composition, dans la mesure où la majorité des observations de la base correspond à de petites firmes n'exportant que de façon occasionnelle. Enfin, nous contrôlons pour la productivité de chaque firme avant l'introduction de la monnaie unique.

Les résultats des estimations sur l'ensemble des firmes montrent que les effets de l'euro sur le commerce passent pour l'essentiel par le canal du nombre de produits exportés par les firmes. Nous notons cependant un impact positif sur la valeur des exportations par produit, lorsque l'échantillon d'exportateurs est réduit aux entreprises de plus de 20 salariés. Ce résultat tend à attester l'existence d'un effet de composition. Finalement, alors que les résultats restent inchangés lorsque l'on contrôle pour la productivité des firmes, nous vérifions aussi que l'impact de l'euro est fortement réduit pour les $25 \%$ des firmes ayant le niveau de productivité le plus bas avant l'introduction de la monnaie unique. 


\section{RESUME COURT}

Nous nous intéressons à l'impact de l'euro sur les exportateurs français. Nous construisons trois marges correspondant à la décision d'exporter, au nombre de produits exportés vers chaque destination et à la valeur moyenne exportée par produit; ces trois marges composent la valeur anticipée de l'exportation de chaque firme individuelle vers un marché. Les résultats des estimations portant sur l'ensemble des exportateurs français suggèrent que l'adoption de l'euro a eu un effet positif sur le nombre de produits exportés par chaque firme, mais n'a pas eu d'impact sur la décision d'exporter ou sur la valeur moyenne des exportations par produit. Toutefois, des effets de composition sont présents: l'impact sur la décision d'exporter, et sur la valeur moyenne des exportations par produit, est positif (mais faiblement significatif) pour les firmes employant plus de 20 salariés. Enfin nous observons que l'euro n'a pas eu d'impact sur les firmes les moins productives.

Classification JEL : F15.

Mots clés : commerce international, marges d'exportation, euro. 


\title{
Euro Effects on Firm and Product-Level Trade Margins
}

\author{
Antoine BERTHOU ${ }^{1}$ \\ Lionel FONTAGNÉ ${ }^{2}$
}

\section{INTRODUCTION}

What are the trade effects of euro adoption? The macroeconomic impact on bilateral trade flows has been widely examined and quantified: the value of trade flows between insiders has increased by less than $10 \%$ since 1999, as compared to other kind of country pairs that can be considered as the control group (Flam and Nordstrom, 2003; Micco et al., 2003; Baldwin, 2006). Though, ten years after the introduction of the single currency, the lack of microeconomic evidence is striking. In an economic policy perspective, it is critical to have a clear description of the adjustments that occurred between and within firms. The issue of the euro effects on trade can examined through a series of questions. How did euro adoption affect the selection of exporters? Can we observe a shift in the number of products exported by firm? Did the value of exports by product within incumbent exporters raise? Which kind of firms benefited from euro adoption? All these questions have remained unexplored.

The single currency was motivated with the aim of reducing transaction/trade costs between eurozone members, promoting price transparency, and thus making the single market work more efficiently. In a theoretical perspective, the New New Trade Theory is helpful to identify the micro-level adjustments that we should expect. Recent developments in trade theory have indeed emphasized that the adjustments consecutive to a decrease in trade costs can occur through the selection of firms (the firm-level trade margins), through the within-firm section of products that are exported (the product extensive margin), and through the value of exports by product (the product intensive margin). In a trade model à la Melitz (2003), reduced trade costs can raise the number of exporters, as well as the value of exports by incumbent firms. In this class of models, firms are considered as mono-product exporters. Though, this is far from being close to what can be observed on the export market: exporters are not only larger and more productive as in Melitz (2003); they also export several products on each market (Mayer and Ottaviano, 2007; Bernard et al., 2006). Recent trade models developed by Eckel and Neary (2006) or Bernard et al. (2006) integrate this feature. In particular, Bernard et al. (2006) show that trade lib-

\footnotetext{
${ }^{1}$ CES, Université Paris I, Paris School of Economics (antoine.berthou@ malix.univ-paris1.fr)

${ }^{2}$ Paris School of Economics, Université Paris I and CEPII (lionel.fontagne@univ-paris1.fr)
} 
eralization contributes to a within-firm product selection on the export market. More precisely, the model predicts that a decrease in trade costs increases the number of products that are exported by each individual firm, as well as the value of exports by products. Hence, one may expect that the euro adoption, through a decrease in trade costs, has contributed to increase the volume of exports between eurozone members through more exporters, more products exported by firm, and a higher value of exports by product.

Testing those transmission mechanisms requires to make use of highly disaggregated trade data. The first strategy that has been implemented in the empirical literature relies on the use of bilateral trade data at the level of the product. ${ }^{3}$ Two related papers by Baldwin and Nino (2006) and Flam and Nordstrom (2007) find some evidence that the effects of euro adoption on trade channeled through a higher number of product categories exported within the eurozone, consistent with the view that euro adoption shrunk the fixed cost of exporting to eurozone partners. Though, product-level trade databases do not really allow to test the predictions of the New New Trade Theory. With 5,000 product categories in the data, one cannot really identify the firm-level adjustments, consecutive to the euro adoption. For instance, Berthou and Fontagne (2008) make use of export data at the firm-level provided by the French customs. They report that 100,000 French firms export each year. Hence, several firms export within each product category each year. Berthou and Fontagne (2008) also report that French firms are typically multi-product: firms that operate on eurozone markets export on average nearly 7 product categories. These stylized facts emphasize that using product-level trade data does not enable to test the predictions of the New New Trade Theory. Accordingly, previous approach by Baldwin and Nino (2006) and Flam and Nordstrom (2007) that rely on product-level trade data do not allow to identify the adjustments that may occur (1) between firms through the selection process, and (2) within firms through the number of products exported by firm and the value of exports by product.

Using firm-level export data allows to identify properly all the margins of adjustment that have been explored by the New New Trade Theory. Using such data for Belgium, France and Hungary, Baldwin et al. (2008) investigate the effects of the euro introduction on the firm-level and product-level trade margins. Findings based on simple descriptive statistics indicate that the number of products exported by French firms to eurozone destinations raised by 1999 , as compared to other destinations. Findings are similar for the number of destinations by product by firm in French and Belgian data.

\footnotetext{
${ }^{3}$ Typically, those databases display bilateral trade flow data within 5,000 product categories
} 
While the descriptive statistics displayed in Baldwin et al. (2008) offer a first overview of the possible transmission channels of the euro at the micro-level, unconditional evidence requires a careful econometric analysis. Such analysis is provided by Berthou and Fontagne (2008) with French firm-level export data, where a variety is defined as a product category exported by a single firm. Estimation results show that euro adoption contributed to increase the number of varieties exported by French firms to eurozone destinations, as compared to non-eurozone destinations. This last contribution provides a first empirical validation of the newly-traded goods channel proposed by Baldwin and Taglioni (2004) - the euro introduction may have generated an incentive for firms to export more goods to more destinations within the eurozone.

The strategy adopted by Berthou and Fontagne (2008) relies on the use of firm-level data to compute trade margins at the country-industry level. Such strategy can be refined by making use of the individual dimension of the firm-level trade data to investigate the euro effects on individual exporters. Two issues can be addressed: (1) What are the euro effects on the export decision, on the number of products exported by individual firms, and on the value of exports by product? (2) How firm-level characteristics can influence the reaction of each individual firm exporter?

This paper makes use of the French firm-level export data provided by the French customs, over the period 1995-2003, to investigate these issues that have remained unexplored. We also make use of a French business survey ("Enquête Annuelle d'Entreprises, EAE") that reports the individual characteristics of French firms with more than 20 employees. This second database can be matched with the customs data to investigate how the euro effects on French exporters interact with their individual characteristics, in particular their size and productivity. ${ }^{4}$

First, we successively estimate the effects of the introduction of the euro on the export decision, the number of products exported by firm, and the value of exports by product by firm, for the full sample of French exporters. Second, we investigate whether the estimation results for the full sample of firms are subject to a composition effect. A majority of observation in the data relate to very small firms that export only occasionally. These firms ship typically small amounts of their goods. Hence, these exporters may drive down the results on the intensive margin. We therefore make use of the business survey (EAE) to estimate the euro effects on exporters with more than 20 employees. This enables to explore the existence of a composition effect, when estimation results rely on the full sample of exporters. Finally, we control for

\footnotetext{
${ }^{4} \mathrm{~A}$ similar strategy is implemented in an ongoing work by Nitsch and Pisu (2008) on Belgian data.
} 
productivity, and examine whether the euro effects interact with the productivity of the firm before the euro introduction.

Estimation results that rely on the full sample of exporters show that the effects of the euro on trade mainly channel through the number of products exported by firm in the French case. We note however a positive effect on the value of exports by product, when we restrict the sample of exporters to firms with more than 20 employees. This tends to support the existence of a composition effect. Finally, results remain unchanged when we control for the productivity of the firm. We also find evidence that the euro effect is dramatically reduced for the $25 \%$ of firms reporting the lowest productivity level before 1999 .

The rest of this paper proceeds as follows. Section 1 presents the data and the empirical methodology. Section 2 presents the estimation results. Section 3 concludes.

\section{Data AND Methodology}

\subsection{Data}

This paper on French exporters takes benefit of the existence of two data bases. The first data set is used to estimate the impact of the introduction of the euro on, the probability of exporting to a given destination, the number of products exported by firm, and the value of individual shipments by firms. The combination of the two data sets authorizes in a second step to control for individual characteristics of exporters.

The first dataset, provided by the French customs, comprises all individual French exporters. We keep only records for which the firm, but also the destination market and the product code are available. ${ }^{5}$ All exporting firms located in France are considered. Accordingly, these exporters can belong to the manufacturing sector or to the service sector: what matters is to export a product, not a service. Indeed, not all exported products are manufactures, and we restrict our sample of trade flows to the manufactured products (including agro-food). ${ }^{6}$ An elementary record comprises the

\footnotetext{
${ }^{5}$ Actually, thresholds are present in the original database due to simplified declarations of small exporters. To put in a nutshell, very small exports are not recorded, and small exports are recorded in a simplified manner: the product code is not recorded for instance. Also, the thresholds are different between exports to the European community and toward third countries. Lastly, the former threshold is varying over time. We harmonies the threshold for intra-EU exports to 150,000 euros a year for an exporter. This total value of export is calculated on the basis of the sum of all shipments to the EU by a single firm.

${ }^{6}$ The selection criterion used here is the nature of the product and not the main activity of the firm.
} 
SIREN identification number of the firm, the NC8 code of the product (some 10,000 different headings in total), the ISO code of the destination country (we keep the main 50 destinations), the FOB value of the flow and the quantity shipped.

The second data base is the annual business survey for all firms larger than $20 \mathrm{em}$ ployees located in France (Enquete Annuelle d'Entreprises, EAE thereafter). This data contains exporters as well as non exporters, in all sectors. The identification number of the firm is their SIREN, which authorizes to match this data with custom data. A series of information are provided, such as the wage bill, the number of employees, the value added, the investment, etc.

To conclude, the elementary observation we are interested in is two-dimensional (firms $x$ destination). It can be either the presence of one firm on one of the 50 markets in a given year; it can be the number of products exported by this firm to this market in this year: lastly, it can be the average value of the shipments of this firm to this market in this year (whatever the number of products is exported).

With some 100,000 exporters each year, some 6,000 different headings in the product classification corresponding to manufactured products, with 50 destinations and 9 years, we have potentially 45 million observations $(100,000 \times 50 \times 9) .{ }^{7}$ These 45 million observations correspond to the maximum number of shipments of French firms, each exporting to each market (each year), in the perspective of the traditional New Trade Theory. Though, the picture of French exports is dominated by zeros: exporters only export to few destinations and not all years. To illustrate this let's consider the sample of firms having exported at least one product to one market in one year over the period considered: we are left with only 6.6 million observations. Now, it is clear that some of these firms may have disrupted their shipments at some point. Accordingly, there are still numerous zeros among the 6.6 million observations left. Dropping all the zeros, we are left with 2.3 million positive observations out of 6.6 million. All in all, we have some 43 million zeros out of 45 million possible observations. Among the 2.3 million positive flows, we get 0.7 million shifters (firms exporting to one market in a given year and stopping at some point to do so. This leaves us with 1.6 million observations for non-shifters, corresponding to firm-market pairs continuously observed throughout the 1995-2003 period (Figure 1). The presence of $95 \%$ of zeros in the data not only illustrates an empirical regularity; it also

\footnotetext{
${ }^{7}$ Notice that there is a large turnover in the sample. Each year some 20,000 new firms enter in the sample, while a similar number disappears. Accordingly, some 300,000 different firms are present at some point in the database. By sake of simplicity, we do not exploit this dimension of the data and rely on exporters actually observed each year.
} 
strongly constraints the estimation strategy to be adopted.

Figure 1: Count of observations: all French exporters, 1995-2003

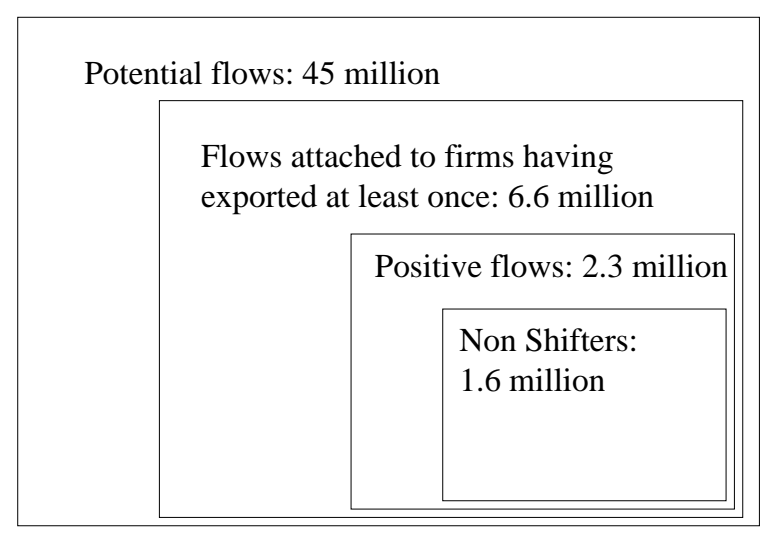

All exporters (conditional to reporting thresholds) are present in the custom database. On the contrary, the business survey is conducted only on firms larger than $20 \mathrm{em}$ ployees. In the two databases, individual firms are identified with the same identification number. We will refer in the following to the first sample of firms as the "full sample" and to the latter as the "restricted sample".

\subsection{Estimation methodology}

\subsubsection{The components of firm-level exports}

We are interested in measuring whether euro adoption had a differentiated effect on the value of exports by French firms to eurozone destinations. But most importantly, the aim of our analysis is to go deeper into the details, in order to determine whether the effect of the euro channeled through the entry decision on the export market (the firm-level extensive margin), the number of products exported by firm (the productlevel extensive margin), or the average value of exports by product (the product-level 
intensive margin). Our data cover the period 1995-2003. Hence, we are interested in two sub-periods: the 1995-1998 sub-period (pre-euro period), and the 1999-2003 sub-period (the post-euro period). We also consider two kind of destinations: 9 eurozone destinations (12 less France, less Luxembourg, less Greece) ${ }^{8}$ and 41 other destinations that includes both OECD and developing countries within the rest of the world.

As discussed above, we are interested in the effect of the euro on the various components of the value of exports by each individual firm to a given destination. The expected value of exports by each individual firm $E\left(X_{k j t}\right)$ can be expressed as follows:

$$
E\left(X_{k j t}\right)=\operatorname{Prob}\left(X_{k j t}>0\right) \times E\left(n_{k j t}>0 \mid X_{k j t}>0\right) \times E\left(x_{k j t}>0 \mid X_{k j t}>0\right)
$$

Where $n_{k j t}$ is the number of products exported by firm $k$ to destination $j$, and $x_{k j t}$ is the average value of exports by product, when firm $k$ exports to destination $j$. In our approach, we decompose these three components of the value of exports by firm to a destination, to estimate the effects of the euro on the export decision, the number of products exported and the average value of exports to a partner.

\subsubsection{Estimation strategy for the full sample of exporters}

By simply using the customs database on French exports - and without taking into account the information about firm-level characteristics that are reported in the EAE business survey, we can estimate the euro effects on each of the three components of the value of exports, by each individual firm, over the full sample of exporters. A major issue related to the use of firm-level data, is that variables which are not firmspecific generate as many observations as the number of firms within the panel. We cluster standard errors by destination, each time it is feasible, so as to get consistent significance levels for the estimated coefficients.

We first estimate the euro effect on the probability that a firm exports to a foreign market, $\operatorname{Prob}\left(X_{k j t}>0\right)$. Though, we do not observe the probability of exporting $\operatorname{Prob}\left(X_{k j t}>0\right)$. The dependent variable that is used for estimation, $T_{k j t}$, is a dummy variable that takes the value 1 if the customs database reports that firm $k$ exported to destination $j$ at time $t$, and zero otherwise. In our estimation strategy,

\footnotetext{
${ }^{8}$ Luxembourg is merged with Belgium, so keep the Benelux destination as a whole which drops the corresponding product/destination pairs. Greece is excluded due to rather erratic variations in its exchange rates and lately entry.
} 
we make use of a conditional FE logit, which estimates the effect of each independent variable on the probability that the firm "switches" from the non-exporter to the exporter status. Hence, the estimation procedure drops all observations that correspond to non-switching firms, i.e. firms that continue exporting to a given destination market over the whole 1995-2003 period. For comparison, we also use a linear probability model that we estimate with a within fixed-effect estimator. As compared to the conditional FE logit, the within FE estimator keeps the observations corresponding to non-switching firms for the estimation. Accordingly, we begin by estimating the following equation with the within FE and conditional FE logit estimators:

$$
T_{k j t}=\alpha_{1} E Z_{99-03}+\alpha_{2} \ln \left(R E R_{j t}\right)+\alpha_{3} \ln \left(R G D P_{j t}\right)+\alpha_{4} \kappa_{k j}+\alpha_{5} \kappa_{t}+\epsilon_{k j t}
$$

$E Z_{1999-2003}$ is a dummy variable, which is equal to one during the period 19992003 when the destination country is a member of the eurozone, and zero otherwise. $R E R_{j t}$ is the real exchange rate. $R G D P_{j t}$ is the real GDP. $\kappa_{k j}$ is the fixed effect firm $\times$ destination, which correspond to our individuals in the panel. $\kappa_{t}$ is the set of year dummy variables.

Having estimated the effects of the euro on the firm decision to export to a given destination, we investigate the euro effect on the remaining components of the value of exports by each individual firm on each destination: the number of products exported (the product-level extensive margin) and the average value of exports by product (the product-level intensive margin).

Working with data on the number of products exported by firm raises a major issue: even though many firms are multi-product, they export a discrete number of products to each destination. Hence, taking logs when the dependent variable is the number of products exported to a given destination, and estimating the equation with Ordinary Least Squares, is not feasible. Silva and Tenreyro (2006) also argue that, taking the logs of the dependent variable in the presence of heteroskedasticity, while estimating a gravity-like equation, leads to biased estimates. They therefore recommend to keep the dependent variable in levels and use a poisson estimator. We first rely on a conditional FE poisson estimator, which allows for firm $\times$ destination fixed effects, but does not enable to cluster standard errors by destination. As a control, we use a poisson regression, which enables to cluster standard errors by destination, but does not enable for the firm $\times$ destination fixed effects. ${ }^{9}$

\footnotetext{
${ }^{9}$ In the simple poisson regression, we do control for industry and firm-level characteristics when we rely on the more than 20 employees firms' sample, which allows to use information provided by the EAE business survey.
} 
We keep the control variables that were reported in Equation 2, and estimate the effect of the euro on the number of products exported $n_{k j t}$, and that on the average value of exports by product $x_{k j t}$, using the conditional FE poisson estimator. We estimate those equations on positive trade flows.

$$
\begin{aligned}
& n_{k j t}=\beta_{1} E Z_{99-03}+\beta_{2} \ln \left(R E R_{j t}\right)+\beta_{3} \ln \left(R G D P_{j t}\right)+\beta_{4} \kappa_{k j}+\beta_{5} \kappa_{t}+\epsilon_{k j t} \\
& x_{k j t}=\gamma_{1} E Z_{99-03}+\gamma_{2} \ln \left(R E R_{j t}\right)+\gamma_{3} \ln \left(R G D P_{j t}\right)+\gamma_{4} \kappa_{k j}+\gamma_{5} \kappa_{t}+\epsilon_{k j t}
\end{aligned}
$$

In the case of the estimation with the poisson estimator, we only use one-way destination fixed effects; we also introduce industry fixed effects when it is possible. ${ }^{10}$

\subsubsection{Estimation strategies for different subset of exporters}

As discussed in introduction, we are interested in determining (i) whether the euro effect on very small exporters differs from that on larger exporters, and how it can lead to a composition effect; (ii) how productivity interacts with the euro effect on French exporters. Exploring these two issues requires to make use of the business survey on firms located in France (EAE database), which displays information on firms' characteristics, but only for firms reporting more than 20 employees. We therefore merge the customs database with the EAE database with their SIREN identification number; this enables to identify firms having less than 20 employees (not reported in the EAE database), and firms having more than 20 employees (reported in both databases and for which the EAE provides a number of characteristics).

We first begin by investigating the euro effect on firms with more, or less, than 20 employees. We therefore re-estimate Equations (2), (3) and (4) by relying on the sample of firms with less than 20 employees; we then replicate the estimation of those equations with the sample of firms with more than 20 employees. With this methodology, we are able to investigate the existence of a composition effect. Since firms with less than 20 employees represent a large majority of export flows (though it also represents a tiny fraction of the aggregate export value to each destination), the euro effect on trade in the full sample estimations may be driven by the fact that those firms are in a majority.

Merging the customs and EAE business survey databases also enables to investigate the euro effect on French exporters, according to their productivity. In this preliminary version of the paper, productivity is measured by the annual per capita apparent

\footnotetext{
${ }^{10}$ As discussed previously, it is only possible in the more than 20 employees firms' sample.
} 
productivity (value added divided by employment) of each exporter. This also enables to rank firms according their productivity. For each firm, we compute the average productivity of the period 1995-1998. Then we generate four quartiles according to the firms' average productivity over the same period, and also generate interaction variables between the $E Z_{99-03}$ variable, and the first three quartiles Q1, Q2 and Q3; the fourth quartile is omitted. Hence, the coefficient on each interaction variable can be interpreted as a deviation as compared to the coefficient on the $E Z_{99-03}$ variable, that corresponds to the euro effect for the most productive exporters (in the fourth quartile). With this methodology, we can determine whether the euro effect on French exporters interacts with the initial productivity of firms, that is observed before the introduction of the euro.

\subsection{Stylized facts}

For each year, we have about 100,000 French exporters, exporting 6,000 manufactured products to 50 destination markets. The 20,000 French exporters employing more than 20 employees on which the annual business survey is conducted, account for 80 percent of the value of total French exports. This emphasizes the high concentration of exports, in line with what is observed for other countries (Eaton et al. (2004) and Mayer and Ottaviano (2007)).

While the high concentration of exports among few - but large - exporters has been well documented in recent studies using European and US data, the most interesting feature is that many firms export more than a single product, and can therefore be considered as multi-product exporters. Using the French data, we complete this picture by providing additional evidence that firms are also multi-product on each market, as suggested in Figures 2 and 3. Both figures report the distribution of the number of products exported by each individual firm, on each destination, over the period 1995-2003. Figure 2 reports the distribution for the full sample of destinations, while Figure 3 reports the distribution by restricting for eurozone destinations. The striking fact here is that both Figures report that about $50 \%$ of all firms export more than one product on each market. The number is a bit larger for eurozone though: firms exporting to eurozone destinations are more multi-product.

Figure 4 also reports the distribution of the average value of exports by product, for each individual firm exporting to a given destination. As for the previous Figures for the number of products, we replicate the exercise for the full sample of destinations, and for eurozone destinations. Results here indicate that on average, individual firms have higher values of shipments when they export to eurozone destinations.

In the next section, we turn to the empirical estimates of the euro effects on each 
CEPII, Working Paper No $2008-21$

Figure 2: Distribution of individual exports on each destination (full sample)

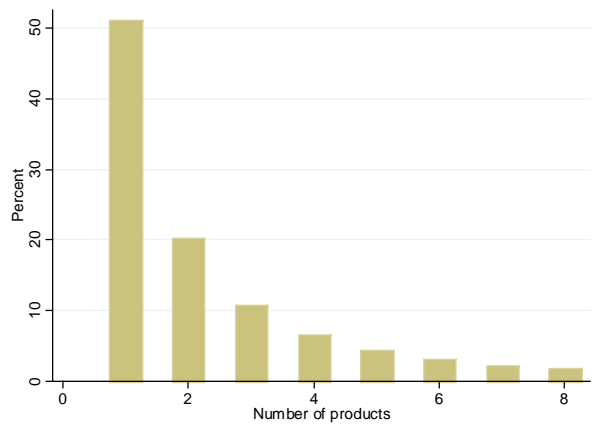

Figure 3: Distribution of individual exports on each destination (eurozone)

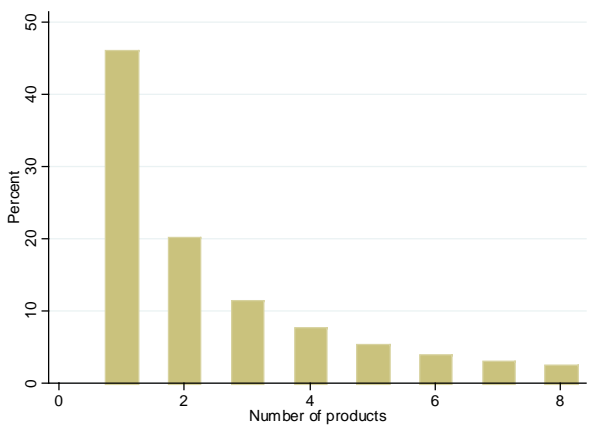


Figure 4: Density of individual exports on each destination

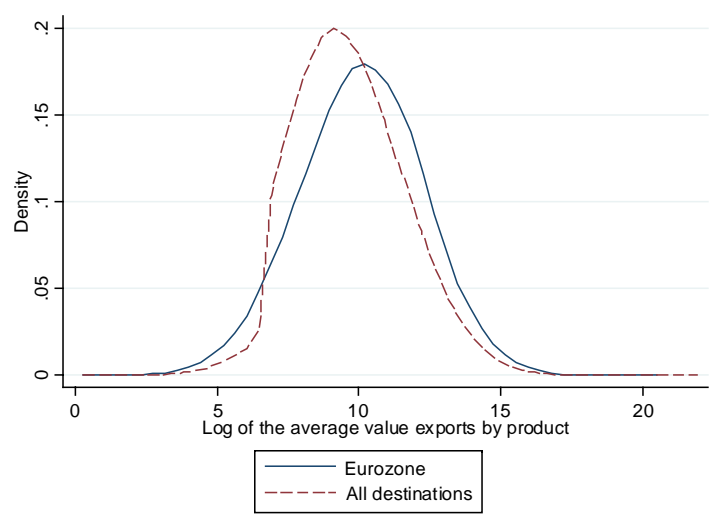

component of the expected value of exports by individual French exporters.

\section{EMPIRICAL RESULTS}

\subsection{Full sample estimates}

As discussed above, the first objective of our approach is to determine whether euro adoption had an effect on the decision of individual firms to enter the export market, the number of products exported by each firm, and the average value of exports by product on a given market. In this first step, we keep the full sample of firms, which represents 6.6 million observations. All estimation results are reported in Table 1 .

We begin with Equation (2) and estimate the euro effect of the probability of exporting to a foreign market. Importantly, we only report the estimated coefficient in the conditional FE logit, and not the marginal effect. Both the linear and non-linear probability models' outputs report that the coefficients in the real exchange rate and the real GDP of the destination have the expected sign: an appreciation of the real exchange rate reduces the probability that a firm exports to a given destination, while the probability of exporting to a foreign market is larger when demand is also larger. Most importantly, estimations report that for the full sample of firms, the euro adoption had no effect on the probability of exporting to eurozone destinations after 1999. 
We then proceed to the estimation of Equations (3) and (4), using successively the conditional FE Poisson and Poisson estimators. As discussed above, the conditional FE poisson enables to use firm $\times$ destination fixed effects, and produces robust standard errors; however, it does not enable to cluster standard errors by destination. We therefore use the Poisson regression as a robustness check to get an estimate of the euro effect by clustering standard errors by destination.

Estimations results with the conditional FE estimator indicate that an appreciation of the real exchange rate has a negative effect, both on the number of products exported by each firm and on the average value of exports by product. Market size (the real GDP) has a positive effect on both components of the product extensive margin. The most striking result comes from the fact that the euro effect on French exporters concentrates on the product extensive margin: the euro adoption actually increased the number of products shipped by exporters to eurozone destinations by 1999 . This result is confirmed in the Poisson regression that allows for clustering standard errors by destination.

Table 1: Estimations full sample

\begin{tabular}{|c|c|c|c|c|c|c|}
\hline \multirow{3}{*}{$\begin{array}{l}\text { Dep. variable } \\
\text { Estimator } \\
E Z_{1999-2003}\end{array}$} & \multicolumn{2}{|c|}{$\overline{P \operatorname{Prob}\left(X_{k j t}>0\right)}$} & \multirow{2}{*}{\multicolumn{2}{|c|}{$\begin{array}{lr}n_{k j t} & x_{k j t} \\
\text { Cond. FE Poisson }\end{array}$}} & \multirow{2}{*}{\multicolumn{2}{|c|}{$x_{k j t}$}} \\
\hline & \multicolumn{2}{|c|}{ Within FE Cond. FE logit } & & & & \\
\hline & $\begin{array}{l}-0.002 \\
(0.007)\end{array}$ & $\begin{array}{c}0.053 \\
(0.056)\end{array}$ & $\begin{array}{c}0.056^{* * *} \\
(0.006)\end{array}$ & $\begin{array}{l}-0.047 \\
(0.068)\end{array}$ & $\begin{array}{c}0.044 * * * \\
(0.012)\end{array}$ & $\begin{array}{c}0.016 \\
(0.074)\end{array}$ \\
\hline$R E R_{j t}$ & $\begin{array}{c}-0.172 * * * \\
(0.031)\end{array}$ & $\begin{array}{c}-1.214 * * * \\
(0.231)\end{array}$ & $\begin{array}{c}-0.319 * * * \\
(0.027)\end{array}$ & $\begin{array}{l}-0.243^{*} \\
(0.132)\end{array}$ & $\begin{array}{l}-0.09 * * \\
(0.045)\end{array}$ & $\begin{array}{c}0.011 \\
(0.203)\end{array}$ \\
\hline$R G D P_{j t}$ & $\begin{array}{c}0.238 * * * \\
(0.036)\end{array}$ & $\begin{array}{c}1.680 * * * \\
(0.267)\end{array}$ & $\begin{array}{c}0.421 * * * \\
(0.034)\end{array}$ & $\begin{array}{c}0.849 * * * \\
(0.207)\end{array}$ & $\begin{array}{c}0.137 * * \\
(0.059)\end{array}$ & $\begin{array}{c}0.137 \\
(0.517)\end{array}$ \\
\hline $\begin{array}{l}\text { Nb observations } \\
\text { SE clustered } \\
\text { Fixed effects }\end{array}$ & $\begin{array}{l}6,653,401 \\
\text { yes } \\
\text { Firm x d }\end{array}$ & $\begin{array}{c}5,061,039 \\
\text { yes } \\
\text { tination, year }\end{array}$ & $\begin{array}{c}2,320,852 \\
\text { no } \\
\text { Firm } x \text { des }\end{array}$ & $\begin{array}{c}2,320,852 \\
\text { no } \\
\text { nation, year }\end{array}$ & $\begin{array}{c}2,626,804 \\
\text { yes } \\
\text { Destina }\end{array}$ & $\begin{array}{c}2,626,804 \\
\text { yes } \\
\text { n, year }\end{array}$ \\
\hline
\end{tabular}

Note: Significance levels: $* 10 \%, * * 5 \%, * * * 1 \%$. All variables - with the exception of dummy variables - are in logarithms. Robust standard errors in parentheses.

We have estimated the effects of the euro on French exports by relying on the full sample of firms. We next replicate the exercise, by relying on restricted samples of firms. 


\subsection{Sub-samples of firms}

As discussed in the previous sections, merging of the customs database with the EAE business survey enables to identify the individual characteristics of the French exporters. We take this opportunity to identify very small firms (with less than 20 employees), for which the individual characteristics are not available in the EAE business survey. We then estimate equations (2), (3) and (4) by restricting the sample to firms with less than 20 employees, or more than 20 employees. Since the first sub-sample contains a majority of small exporters, we are able to identify whether our previous results are subject to a composition effect.

We begin with the sample of firms with less than 20 employees. The first striking fact is that those firms represent 5.6 million observation, over 6.6 million observations in the full sample. Results for this restricted sample are very much in line with previous estimates for the full sample. The euro had no effect on the decision to enter new eurozone destinations, and no effect on the average value of exports by product to each destination, by individual firm. The euro effect concentrates on the number of products exported. Though, clustering standard errors in the Poisson regression leaves this last effect much less significant.

Table 2: Estimations small firms ( $<20$ employees)

\begin{tabular}{|c|c|c|c|c|c|c|}
\hline \multirow{2}{*}{$\begin{array}{l}\text { Dep. variable } \\
\text { Estimator }\end{array}$} & \multicolumn{2}{|c|}{$\overline{\operatorname{Prob}}\left(X_{k j t}>0\right)$} & \multirow{2}{*}{\multicolumn{2}{|c|}{$\begin{array}{lr}n_{k j t} & x_{k j t} \\
\text { Cond. FE Poisson }\end{array}$}} & \multirow{2}{*}{\multicolumn{2}{|c|}{$n_{k j t}{ }_{\text {Poisson }}^{x_{k j t}}$}} \\
\hline & Within FE & Cond. FE logit & & & & \\
\hline$E Z_{1999-2003}$ & $\begin{array}{c}0.004 \\
(0.007)\end{array}$ & $\begin{array}{c}0.036 \\
(0.055)\end{array}$ & $\begin{array}{c}0.085 * * * \\
(0.011)\end{array}$ & $\begin{array}{l}-0.155 \\
(0.134)\end{array}$ & $\begin{array}{l}0.109^{*} \\
(0.021)\end{array}$ & $\begin{array}{l}-0.023 \\
(0.104)\end{array}$ \\
\hline$R E R_{j t}$ & $\begin{array}{c}-0.153 * * * \\
(0.027)\end{array}$ & $\begin{array}{c}-1.099 * * * \\
(0.205)\end{array}$ & $\begin{array}{c}-0.367 * * * \\
(0.047)\end{array}$ & $\begin{array}{l}-0.161 \\
(0.285)\end{array}$ & $\begin{array}{c}-0.136^{* *} \\
(0.066)\end{array}$ & $\begin{array}{c}0.145 \\
(0.320)\end{array}$ \\
\hline$R G D P_{j t}$ & $\begin{array}{c}0.212 * * * \\
(0.035)\end{array}$ & $\begin{array}{c}1.516^{* * * *} \\
(0.255)\end{array}$ & $\begin{array}{c}0.288 * * * \\
(0.055)\end{array}$ & $\begin{array}{l}0.816^{*} \\
(0.424)\end{array}$ & $\begin{array}{l}-0.043 \\
(0.097)\end{array}$ & $\begin{array}{c}0.077 \\
(0.720)\end{array}$ \\
\hline $\begin{array}{l}\text { Nb observations } \\
\text { SE clustered } \\
\text { Fixed effects }\end{array}$ & $\begin{array}{l}5,654,822 \\
\text { yes } \\
\text { Firm x de }\end{array}$ & $\begin{array}{c}4,509,617 \\
\text { yes } \\
\text { tination, year }\end{array}$ & $\begin{array}{c}1,363,496 \\
\text { no } \\
\text { Firm x des }\end{array}$ & $\begin{array}{c}1,363,496 \\
\text { no } \\
\text { ation, year }\end{array}$ & $\begin{array}{c}1,797,874 \\
\text { yes } \\
\text { Destina }\end{array}$ & $\begin{array}{c}1,797,874 \\
\text { yes } \\
\text { on, year }\end{array}$ \\
\hline
\end{tabular}

Note: Significance levels: $* 10 \%, * * 5 \%, * * * 1 \%$. All variables - with the exception of dummy variables - are in logarithms. Robust standard errors in parentheses.

We then proceed to the same estimates on the restricted sample of firms having more than 20 employees. This leaves us with less than 1 million observations, over 6.6 million observations in the full sample.

The first observation to be made relates to the persistence of exports in the sub-sample 
of firms below 20 employees compared to larger firms. Considering the less than 20 employees, we get 5.6 million observations with the within FE estimator and 4.5 million observations with the conditional FE logit that drops the non-switchers (here one observation out of four). On the contrary, considering the restricted sample of firms larger than 20 employees, the within FE estimator is using 0.9 million observations and the conditional FE logit 0.3 million observations. This leaves us with two observations out of three that correspond to exports flows observed throughout the period. We conclude to the high persistence of exports of firms larger than 20 employees.

As compared to previous estimates, we can observe noticeable differences in the estimated effects of the euro on French exporters. First, while the coefficient on the euro variable conditional FE logit is not significant, the linear probability model reports a significant and positive effect of euro adoption on the decision to export to new destinations. Second, while we still observe a positive and very significant effect of the euro on the number of products exported to eurozone destinations, estimations also report a positive effect on the average value of exports by product, even when standard errors are clustered by destination in the poisson regression. Though the effect remains weakly significant, this raises the possibility of a composition effect when we rely on the full sample.

Table 3: Estimations on restricted sample (firms $>20$ employees)

\begin{tabular}{|c|c|c|c|c|c|c|}
\hline \multirow{2}{*}{$\begin{array}{l}\text { Dep. variable } \\
\text { Estimator }\end{array}$} & \multicolumn{2}{|c|}{$\overline{P \operatorname{Prob}\left(X_{k j t}>0\right)}$} & \multirow{2}{*}{\multicolumn{2}{|c|}{$\begin{array}{lr}n_{k j t} & x_{k j t} \\
\text { Cond. FE Poisson }\end{array}$}} & \multirow{2}{*}{\multicolumn{2}{|c|}{$\begin{array}{r}x_{k j t} \\
\text { Poisson }\end{array}$}} \\
\hline & \multicolumn{2}{|c|}{ Within FE Cond. FE logit } & & & & \\
\hline$E Z_{1999-2003}$ & $\begin{array}{c}0.037 * * * \\
(0.008)\end{array}$ & $\begin{array}{c}0.133 \\
(0.085)\end{array}$ & $\begin{array}{l}0.04 * * * \\
(0.006)\end{array}$ & $\begin{array}{l}0.042^{*} \\
(0.025)\end{array}$ & $\begin{array}{c}0.026^{* *} \\
(0.010)\end{array}$ & $\begin{array}{l}0.077 * \\
(0.044)\end{array}$ \\
\hline$R E R_{j t}$ & $\begin{array}{c}-0.175 * * * \\
(0.050)\end{array}$ & $\begin{array}{c}-1.517 * * * \\
(0.321)\end{array}$ & $\begin{array}{c}-0.239 * * * \\
(0.030)\end{array}$ & $\begin{array}{c}-0.344 * * * \\
(0.119)\end{array}$ & $\begin{array}{c}-0.105^{* *} \\
(0.048)\end{array}$ & $\begin{aligned}-0.303^{*} \\
(0.168)\end{aligned}$ \\
\hline$R G D P_{j t}$ & $\begin{array}{l}0.130^{*} \\
(0.069)\end{array}$ & $\begin{array}{c}2.285 * * * \\
(0.555)\end{array}$ & $\begin{array}{c}0.469 * * * \\
(0.045)\end{array}$ & $\begin{array}{c}0.868 * * * \\
(0.224)\end{array}$ & $\begin{array}{c}0.154 * * \\
(0.065)\end{array}$ & $\begin{array}{c}0.391 \\
(0.390)\end{array}$ \\
\hline Nb observations & 998,579 & 305,105 & 782,982 & 782,982 & 828,789 & 828,789 \\
\hline SE clustered & yes & yes & no & no & yes & yes \\
\hline Fixed effects & Firm x d & tination, year & Firm $\mathrm{x}$ des & nation, year & Destinatic & ndustry, year \\
\hline
\end{tabular}

Note: Significance levels: $* 10 \%, * * 5 \%, * * * 1 \%$. All variables - with the exception of dummy variables - are in logarithms. Robust standard errors in parentheses.

In the next estimates, we control for productivity and investigate how the productivity level of firms, prior to the introduction of the euro, interacts with the euro effect on French exporters. 


\subsection{Euro effect and productivity}

In previous estimates, we relied on firm-level fixed effects to control for individual characteristics. Though, this method does not enable to control for time-varying characteristics at the firm level. We therefore use the restricted sample of firms with more than 20 employees, and control for the apparent productivity (value added/number of employees) computed with the EAE database. Note that we lag productivity one year to avoid reverse causality. ${ }^{11}$ We report estimates in Table 4.

Not surprisingly, even when controlling for time invariant firms x destination effects, lagged productivity has a positive impact on the decision to export, as well as on the intensive and extensive margins. More interestingly, results are very similar to those obtained without controlling for productivity: comparing with Table 3, where only individual fixed effects were used, the effect of euro introduction on the decision to export and on the number of products are similar. The only difference concerns the impact on the value of exports by product. While the conditional FE Poisson leads to the same conclusion with and without controlling for the productivity, the Poisson now fails to capture a positive impact of euro introduction on the value of exports by product.

We then interact the euro dummy with the productivity quartiles to estimate the differentiated impact of euro introduction on firms having different productivity levels before 1999. In the first row of Table 5, we report the average impact of euro introduction on the decision to export and on the two margins, for the restricted sample of firms larger than 20 employees. The three next rows report the deviations for the first, second and third quartiles of productivity (1995-98 average), as compared to the fourth quartile. We keep the control for time varying individual lagged productivity as well as firms $\mathrm{x}$ destination fixed effects).

Using the within FE estimator, we observe that the positive effect of euro introduction on the decision to export is less pronounced for the least productive firms. The impact is positive on average for firms reporting higher productivity levels. There is no statistically significant difference in the effect for firms of the second and third quartiles of productivity, as compared to the quartile of most efficient firms.

Concerning the product extensive margin, and considering results for the conditional FE Poisson, there is no difference in the positive impact of euro introduction for the second and third productivity quartiles compared to the quartile of most efficient firms, while the effect completely vanishes for the first quartile. This reinforces the

\footnotetext{
${ }^{11} \mathrm{~A}$ firm must accordingly be observed as an exporter to a given market in two consecutive years. However, remind that two third of trade flows are observed each year in the restricted sample of firms larger than 20 employees.
} 
Table 4: Estimations restricted sample (firms $>20$ employees), controls for productivity

\begin{tabular}{|c|c|c|c|c|c|c|}
\hline \multirow{3}{*}{$\begin{array}{l}\text { Dep. variable } \\
\text { Estimator } \\
E Z_{1999-2003}\end{array}$} & \multicolumn{2}{|c|}{$\operatorname{Prob}\left(X_{k j t}>0\right)$} & \multirow{2}{*}{\multicolumn{2}{|c|}{$\begin{array}{lr}n_{k j t} & x_{k j t} \\
\text { Cond. FE Poisson }\end{array}$}} & \multirow{2}{*}{\multicolumn{2}{|c|}{$n_{k j t} x_{k j t}$}} \\
\hline & Within FE & Cond. FE logit & & & & \\
\hline & $\begin{array}{c}0.035 * * * \\
(0.008)\end{array}$ & $\begin{array}{c}0.124 \\
(0.085)\end{array}$ & $\begin{array}{l}0.040 * * * \\
(0.006)\end{array}$ & $\begin{array}{l}0.044^{*} \\
(0.025)\end{array}$ & $\begin{array}{l}0.024 * * \\
(0.010)\end{array}$ & $\begin{array}{c}0.060 \\
(0.046)\end{array}$ \\
\hline$R E R_{j t}$ & $\begin{array}{c}-0.174 * * * \\
(0.050)\end{array}$ & $\begin{array}{l}-1.520 * * * \\
(0.323)\end{array}$ & $\begin{array}{c}-0.237 * * * \\
(0.030)\end{array}$ & $\begin{array}{c}-0.328 * * * \\
(0.119)\end{array}$ & $\begin{array}{c}-0.114 * * \\
(0.048)\end{array}$ & $\begin{array}{l}-0.295^{*} \\
(0.176)\end{array}$ \\
\hline$R G D P_{j t}$ & $\begin{array}{l}0.132 * \\
(0.068)\end{array}$ & $\begin{array}{l}2.295 * * * \\
(0.554)\end{array}$ & $\begin{array}{c}0.473 * * * \\
(0.045)\end{array}$ & $\begin{array}{c}0.893 * * * \\
(0.224)\end{array}$ & $\begin{array}{c}0.200 * * * \\
(0.066)\end{array}$ & $\begin{array}{c}0.511 \\
(0.407)\end{array}$ \\
\hline Prdctvity ${ }_{k, t-1}$ & $\begin{array}{c}0.019 * * * \\
(0.002)\end{array}$ & $\begin{array}{c}0.185 * * * \\
(0.018)\end{array}$ & $\begin{array}{c}0.044 * * * \\
(0.005)\end{array}$ & $\begin{array}{c}0.113 * * * \\
(0.027)\end{array}$ & $\begin{array}{c}0.246 * * * \\
(0.011)\end{array}$ & $\begin{array}{c}0.588 * * * \\
(0.020)\end{array}$ \\
\hline $\begin{array}{l}\text { Nb observations } \\
\text { SE clustered } \\
\text { Fixed effects }\end{array}$ & $\begin{array}{l}\text { 991,303 } \\
\text { yes } \\
\text { Firm }\end{array}$ & $\begin{array}{c}299,747 \\
\text { yes } \\
\text { dest }^{\circ} \text {, year }\end{array}$ & $\begin{array}{c}777,833 \\
\text { no } \\
\text { Firm x }\end{array}$ & $\begin{array}{c}777,833 \\
\text { no } \\
\text { st }^{\circ}, \text { year }\end{array}$ & $\begin{array}{c}791,666 \\
\text { yes } \\
\text { Dest }^{\circ}, \text { in }\end{array}$ & $\begin{array}{c}791,666 \\
\text { yes } \\
\text { stry, year }\end{array}$ \\
\hline
\end{tabular}

Note: Significance levels: $* 10 \%, * * 5 \%, * * * 1 \%$. All variables - with the exception of dummy variables - are in logarithms. Robust standard errors in parentheses.

new good hypothesis: the impact of euro introduction on the selection of exporters is twofold, reduction in transaction costs, but also increased competition. The latter effect strictly compensates the former for the least efficient exporters, and there is no net effect on the number of exported products for these firms. ${ }^{12}$. This conclusion is reinforced by the Poisson estimate: the positive impact of euro introduction is concentrated on the fourth quartile, is reduced for the third quartile, and vanishes for the second and first quartiles of productivity.

This differentiated impact of euro introduction on the least productive exporters is also confirmed when it comes to the product intensive margin. The conditional FE Poisson concludes to a positive impact of euro introduction on average for firms larger than 20 employees. This effect holds for firms belonging to the second and third quartile of productivity. On the contrary, the effect is clearly negative for firms in the first quartile. The competitive pressure exerted by euro introduction reduces the value of exports of the less efficient firms.

\footnotetext{
${ }^{12}$ Remind that the fringe of exporters below 20 employees is not considered here.
} 
Euro Effects on Firm and Product-Level Trade Margins

Table 5: Estimations restricted sample (firms $>20$ employees), productivity quartiles

\begin{tabular}{|c|c|c|c|c|c|c|}
\hline \multirow{3}{*}{$\begin{array}{l}\text { Dep. variable } \\
\text { Estimator } \\
E Z_{99-03}\end{array}$} & \multicolumn{2}{|c|}{$\overline{P \operatorname{Prob}\left(X_{k j t}>0\right)}$} & \multirow{2}{*}{\multicolumn{2}{|c|}{$\begin{array}{lr}n_{k j t} & x_{k j t} \\
\text { Cond. FE poisson }\end{array}$}} & \multirow{2}{*}{\multicolumn{2}{|c|}{${ }_{\text {Poisson }}^{x_{k j t}}$}} \\
\hline & Within FE & Cond. FE logit & & & & \\
\hline & $\begin{array}{l}0.037 * * * \\
(0.008)\end{array}$ & $\begin{array}{c}0.089 \\
(0.093)\end{array}$ & $\begin{array}{c}0.048 * * * \\
(0.010)\end{array}$ & $\begin{array}{l}0.056^{*} \\
(0.033)\end{array}$ & $\begin{array}{c}0.101 * * * \\
(0.021)\end{array}$ & $\begin{array}{l}0.059 \\
(0.06)\end{array}$ \\
\hline$E Z_{99-03} \times Q 1$ & $\begin{array}{c}-0.009 * * \\
(0.003)\end{array}$ & $\begin{array}{l}-0.042 \\
(0.073)\end{array}$ & $\begin{array}{c}-0.047 * * * \\
(0.013)\end{array}$ & $\begin{array}{l}-0.071^{*} \\
(0.040)\end{array}$ & $\begin{array}{c}-0.122 * * * \\
(0.038)\end{array}$ & $\begin{array}{l}-0.071 \\
(0.082)\end{array}$ \\
\hline$E Z_{99-03} \times Q 2$ & $\begin{array}{l}-0.002 \\
(0.004)\end{array}$ & $\begin{array}{c}0.055 \\
(0.096)\end{array}$ & $\begin{array}{c}0.004 \\
(0.013)\end{array}$ & & $\begin{array}{c}-0.154 * * * \\
(0.033)\end{array}$ & $\begin{array}{l}-0.044 \\
(0.066)\end{array}$ \\
\hline$E Z_{99-03} \times Q 3$ & $\begin{array}{c}0.003 \\
(0.003)\end{array}$ & $\begin{array}{c}0.127 \\
(0.078)\end{array}$ & $\begin{array}{l}-0.003 \\
(0.012)\end{array}$ & $\begin{array}{c}0.029 \\
(0.046)\end{array}$ & $\begin{array}{c}-0.069 * * * \\
(0.020)\end{array}$ & $\begin{array}{c}0.002 \\
(0.064)\end{array}$ \\
\hline$R E R_{j t}$ & $\begin{array}{c}-0.168 * * * \\
(0.051)\end{array}$ & $\begin{array}{c}-1.526 * * * \\
(0.322)\end{array}$ & $\begin{array}{c}-0.231 * * * \\
(0.030)\end{array}$ & $\begin{array}{c}-0.349 * * * \\
(0.120)\end{array}$ & $\begin{array}{c}-0.127 * * * \\
(0.047)\end{array}$ & $\begin{array}{l}-0.237 \\
(0.161)\end{array}$ \\
\hline$R G D P_{j t}$ & $\begin{array}{l}0.134^{*} \\
(0.068)\end{array}$ & $\begin{array}{c}2.259 * * * \\
(0.550)\end{array}$ & $\begin{array}{c}0.476 * * * \\
(0.045)\end{array}$ & $\begin{array}{l}0.916 * * * \\
(0.226)\end{array}$ & $\begin{array}{l}0.169 * * \\
(0.068)\end{array}$ & $\begin{array}{c}0.489 \\
(0.366)\end{array}$ \\
\hline Productivity $_{k, t-1}$ & $\begin{array}{c}0.019 * * * \\
(0.003)\end{array}$ & $\begin{array}{c}0.189 * * * \\
(0.019)\end{array}$ & $\begin{array}{c}0.044 * * * \\
(0.005)\end{array}$ & $\begin{array}{c}0.095^{* * * *} \\
(0.018)\end{array}$ & $\begin{array}{c}0.072 * * * \\
(0.006)\end{array}$ & $\begin{array}{c}0.423 * * * \\
(0.017)\end{array}$ \\
\hline $\begin{array}{l}\text { Nb observations } \\
\text { SE clustered } \\
\text { Fixed effects }\end{array}$ & $\begin{array}{l}\text { yes } \\
\text { Firm } x\end{array}$ & $\begin{array}{c}293,407 \\
\text { yes } \\
\text { dest }^{\circ} \text {, year }\end{array}$ & $\begin{array}{c}751,087 \\
\text { no } \\
\text { Firm x c }\end{array}$ & $\begin{array}{c}751,087 \\
\text { no } \\
\text { st }^{\circ}, \text { year }\end{array}$ & $\begin{array}{c}758,789 \\
\text { yes } \\
\text { Dest }^{\circ}, \text { inc }\end{array}$ & $\begin{array}{c}758,789 \\
\text { yes } \\
\text { stry, year }\end{array}$ \\
\hline
\end{tabular}

Note: Significance levels: $* 10 \%, * * 5 \%, * * * 1 \%$. All variables - with the exception of dummy variables - are in logarithms. Robust standard errors in parentheses.

\section{Conclusions}

We have addressed in this paper three issues related to the impact of euro introduction on trade, using custom data and business surveys for firms located in France over the period 1995-2003. First, how to estimate the effects of the euro separately on the export decision of individual firms, on the number of products exported and on the average value of exports by product to a partner? Second, as new entrants (of a small size) typically export less, to what extent do composition effects drive the average effect of euro introduction down, when averages are used? And third, how does productivity drive the effect of the euro on heterogenous firms.

Descriptive data stress that firms are multi-product, on each market, which justify to care about the product extensive margin, as well as the product intensive margin. We also observe that firms tend to export more when they export to eurozone markets.

Our econometric results identify a positive effect of euro introduction on the deci- 
sion to export. But this effect is restricted to the firms larger than 20 employees. There is also a positive impact of euro introduction on the product extensive margin. The number of exported products is larger at the firm and destination level, to eurozone markets after the introduction of the single currency. This effect is highly robust. Concerning the product intensive margin - the value of the shipments per product - the positive impact of the euro is restricted once again to the firms larger than 20 employees. This effect actually vanishes in the full sample of firms. These results confirm the presence of a composition effect, but stress that the validation of the new good hypothesis is not subject to the presence of such composition effects. What matters is finally the size of the firm, or more plausibly its efficiency.

This last issue has been finally tackled by controlling for the lagged productivity of the firms. A higher productivity has a positive impact on the decision to export and on both product margins. Ranking firms by their productivity before the introduction of the euro, we observe differentiated impacts of euro introduction on heterogenous firms. The positive impact of euro introduction on the decision to export is weakened for the less productive quartile. Also, the positive impact on the product extensive margin is absent in this quartile. Lastly, the net effect of euro introduction is negative for these low productive firms, as a result of competitive pressure overcompensating the effect of reduced transaction costs. 


\section{REFERENCES}

Baldwin, R., Nino, V. D., Fontagne, L., Santis, R. D., and Taglioni, D. (2008). Study on the impact of the euro on trade and investment. European Economy, Economic papers 321, May.

Baldwin, R. and Taglioni, D. (2004). Positive oca criteria: Microfoundations for the rose effect. COE/RES Discussion Paper Series No. 34.

Baldwin, R. E. (2006). The euro's trade effect. ECB Working Paper N. 594.

Baldwin, R. E. and Nino, V. D. (2006). Euros and zeros: The common currency effect on trade in new goods. NBER Working Papers N. 12673.

Bernard, A. B., Redding, S. J., and Schott, P. K. (2006). Multi-product firms and trade liberalization. NBER Working Papers n. 12782.

Berthou, A. and Fontagne, L. (2008). The euro and the intensive and extensive margins of trade: Evidence from french firm level data. CEPII working paper 2008-06, May.

Eaton, J., Kortum, S., and Kramarz, F. (2004). Dissecting trade: Firms, industries and export destinations. American Economic Review, Papers and Proceedings, 94: $150-154$.

Eckel, C. and Neary, J. P. (2006). Multi-product firms and flexible manufacturing in the global economy. C.E.P.R. Discussion Papers n.5941.

Flam, H. and Nordstrom, H. (2003). Trade volume effects of the euro: Aggregate and sector estimates. IIES Seminar Paper No. 746.

Flam, H. and Nordstrom, H. (2007). Explaining large euro effects on trade: the extensive margin and vertical specialization. Manuscript.

Mayer, T. and Ottaviano, G. (2007). The happy few: the internationalization of european firms. Bruegel Blueprint Series vol. 3, Brussels.

Melitz, M. J. (2003). The impact of trade on intra-industry reallocations and aggregate industry productivity. Econometrica, 71(6):1695-1725.

Micco, A., Stein, E., and Ordoñez, G. (2003). The currency union effect on trade: early evidence from emu. Economic Policy, 18(37):315-356. 
CEPII, Working Paper No 2008 - 21

Nitsch, V. and Pisu, M. (2008). Scalpel please! dissecting the euro's effect on trade. mimeo.

Silva, J. M. C. S. and Tenreyro, S. (2006). The log of gravity. The Review of Economics and Statistics, 88(4):641-658. 


\section{LIST OF WORKING PAPERS RELEASED BY CEPII ${ }^{1}$}

No

Title

2008-20 The Impact of Economic Geography on Wages: Disentangling the Channels of Influence

2008-19 Do Corporate Taxes Reduce Productivity and Investment at the Firm Level? Cross-Country Evidence from the Amadeus Dataset

2008-18 Choosing Sensitive Agricultural Products in Trade Negotiations

2008-17 Government Consumption Volatility and Country Size

2008-16 Inherited or Earned? Performance of Foreign Banks in Central and Eastern Europe

2008-15 The Effect of Foreign Bank Entry on the Cost of Credit in Transition Economies. Which Borrowers Benefit most?

2008-14 Contagion in the Credit Default Swap Market: the Case of the GM and Ford Crisis in 2005.

2008-13 Exporting to Insecure Markets: A Firm-Level Analysis

2008-12 Social Competition and Firms' Location Choices

2008-12 Social Competition and Firms' Location Choices

2008-11 Border Effects of Brazilian States

2008-10 International Trade Price Indices

2008-10 International Trade Price Indices

\section{Authors}

L. Hering \& S. Pondet

J. Arnold \&

C. Schwellnu

S. Jean,

D. Laborde

\& W. Martin

D. Furceri

\& M. Poplawski

Ribeiro

O. H avrylchyk \& E. Jurzyk

H. Degryse, O. Havrylchyk, E. Jurzyk \& S. Kozak

V. Coudert \& M. Gex

M. Crozet, P. Koenig \& V. Rebeyrol

V. Delbecque, I. Méjean \& L. Patureau

V. Delbecque, I. Méjean \& L. Patureau

M. Daumal \& S. Zignago

G. Gaulier, J. Martin,

I. Méjean \& S. Zignago

G. Gaulier, J. Martin, I. Méjean \& S. Zignago

\footnotetext{
Working papers are circulated free of charge as far as stocks are available; thank you to send your request to CEPII, Sylvie Hurion, 9, rue Georges-Pitard, 75015 Paris, or by fax : (33) 0153685504 or by e-mail Hurion@cepii.fr. Also available on: \|www.cepii.fr. Working papers with * are out of print. They can nevertheless be consulted and downloaded from this website.
} 
2008-09 Base de données CHELEM - Commerce international du CEPII

2008-08 The Brain Drain between Knowledge Based Economies: the European Human Capital Outflows to the US

2008-07 Currency Misalignments and Exchange Rate Regimes in Emerging and Developing Countries

2008-06 The Euro and the Intensive and Extensive Margins of Trade: Evidence from French Firm Level Data

2008-05 On the Influence of Oil Prices on Economic Activity and Other Macroeconomic and Financial Variables

2008-04 An Impact Study of the EU-ACP Economic Partnership Agreements (EPAs) in the Six ACP Regions

2008-03 The Brave New World of Cross-Regionalism

2008-02 Equilibrium Exchange Rates: a Guidebook for the Euro-Dollar Rate

2008-01 How Robust are Estimated Equilibrium Exchange Rates? A Panel BEER Approach

2007-24 Testing the Finance-Growth Link: Is there a Difference between Developed and Developing Countries?

2007-23 Labor Migration: Macoeconomic and Demographic outlook for Europe and Neighborhood Regions

2007-22 Economic Geography, Spatial Dependence and Income Inequality in China

2007-21 Does FDI in Manufacturing Cause FDI in Business Services? Evidence from French Firm-Level Data

2007-20 Bilateral Trade of Cultural Goods

2007-19 China and India in International Trade: from Laggards to Leaders?
A. de Saint Vaulry

A. Tritah

V. Coudert \& C. Couharde

A. Berthou \& L. Fontagné

F. Lescaroux \& V. Mignon

L. Fontagné, D. Laborde \& C. Mitaritonna

A. Tovias

A. Bénassy-Quéré,

S. Béreau \& V. Mignon

A. Bénassy-Quéré, S. Béreau \& V. Mignon

G. Dufrénot, V. Mignon \& A. Péguin-Feissolle V. Borgy \& X. Chojnicki

L. Hering \& S. Poncet

B. Nefussi \& C. Schwellnus

A.C. Disdier, S.H.T. Tai, L. Fontagné \& T. Mayer

F. Lemoine \& D. Ünal-Kesenci 


\section{CEPII \\ DOCUMENTS DE TRAVAIL / WORKING PAPERS}

Si vous souhaitez recevoir des Documents de travail, merci de remplir le coupon-réponse ci-joint et de le retourner à :

Should you wish to receive copies of the CEPII's Working papers, just fill the reply card and return it to:

Sylvie HURION - Publications

CEPII - 9, rue Georges-Pitard - 75740 Paris - Fax : (33) 1.53.68.55.04

sylvie.hurion@cepii.fr

M./Mme / Mr./Mrs

Nom-Prénom / Name-First name

Titre / Title.....

Service / Department

Organisme / Organisation

Adresse / Address.

Ville \& CP / City \& post code.

Pays / Country...... Tél.

Your e-mail

Désire recevoir les Document de travail du CEPII $n^{\circ}$ :

Wish to receive the CEPII's Working Papers No:

Souhaite être placé sur la liste de diffusion permanente (pour les bibliothèques)

Wish to be placed on the standing mailing list (for Libraries). 